OPEN ACCESS

Edited by: Jingqiang Tan,

Central South University, China

Reviewed by:

Chuanbo Shen,

China University of Geosciences

Wuhan, China

Mianmo Meng,

China University of Petroleum,

Huadong, China

Changan Shan,

Xi'an Shiyou University, China

*Correspondence: Kun Zhang shandongzhangkun@126.com

Specialty section: This article was submitted to Economic Geology,

a section of the journal

Frontiers in Earth Science

Received: 25 August 2021 Accepted: 02 December 2021 Published: 22 December 2021

Citation:

Zhang Z, Zhang $K$, Song $Y$, Jiang $Z$, Jiang $S$, Wang $P, L i Y$, Yin $X$, Chen $Z$,

Li Z, Yuan X, Liu P, Han F, Tang L, Yang $Y$ and Zeng $Y$ (2021) Study on the Formation Mechanism of Shale Roof, Floor Sealing, and Shale Self-Sealing:

A Case of Member I of the Upper Ordovician Wufeng Formation-Lower Silurian Longmaxi Formation in the Yangtze Region.

Front. Earth Sci. 9:764287. doi: 10.3389/feart.2021.764287

\section{Study on the Formation Mechanism of Shale Roof, Floor Sealing, and Shale Self-Sealing: A Case of Member I of the Upper Ordovician Wufeng Formation-Lower Silurian Longmaxi Formation in the Yangtze Region}

\author{
Ziya Zhang ${ }^{1,2,3}$, Kun Zhang ${ }^{4,5,6,7 *}$, Yan Song ${ }^{1,2}$, Zhenxue Jiang ${ }^{1,2}$, Shu Jiang ${ }^{6,7}$, \\ Pengfei Wang ${ }^{8}$, Yong $\mathrm{Li}^{9}$, Xiangdong Yin ${ }^{1,4,5}$, Zhiyuan Chen ${ }^{10}$, Zhengwei $\mathrm{Li}^{11}$, \\ Xuejiao Yuan ${ }^{4,5}$, Pei Liu ${ }^{4,5}$, Fengli Han ${ }^{4,5}$, Liangyi Tang ${ }^{4,5}$, Yiming Yang ${ }^{4,5}$ and Yao Zeng ${ }^{4,5}$ \\ ${ }^{1}$ State Key Laboratory of Petroleum Resources and Prospecting, China University of Petroleum, Beijing, China, ${ }^{2}$ Unconventional \\ Petroleum Research Institute, China University of Petroleum, Beijing, China, ${ }^{3}$ Chinese Academy of Geological Sciences, Beijing, \\ China, ${ }^{4}$ School of Geoscience and Technology, Southwest Petroleum University, Chengdu, China, ${ }^{5}$ State Key Laboratory of Oil \\ and Gas Reservoir Geology and Exploitation, Southwest Petroleum University, Chengdu, China, ${ }^{6}$ Key Laboratory of Tectonics \\ and Petroleum Resources, China University of Geosciences, Ministry of Education, Wuhan, China, ${ }^{7}$ Energy and Geoscience \\ Institute, University of Utah, Salt Lake City, UT, United States, ${ }^{8}$ Geoscience Documentation Center, China Geological Survey, \\ Beijing, China, ${ }^{9}$ Research Institute of Petroleum Exploration and Development, PetroChina Southwest Oilfield Company, \\ Chengdu, China, ${ }^{10} \mathrm{CNPC}$ Managers Training Institute, Beijing, China, ${ }^{11}$ School of Environment and Resource, Southwest \\ University of Science and Technology, Mianyang, China
}

Similar to North America, China has abundant shale resources. Significant progress has been made in the exploration and exploitation of shale gas in China since 2009. As the geological theory of unconventional oil and gas was proposed, scientists have started researching conditions for shale gas preservation. The shale roof and floor sealing and the shale self-sealing are the critical objects of such research, which, however, are still in the initial stage. This article studies the formation mechanism of shale roof and floor sealing and shale self-sealing by taking marine shales from Member I of the upper Ordovician Wufeng Formation-lower Longmaxi Formation in the upper Yangtze region as the research object. Analyses were performed on the TOC content, mineral composition, and porosity, as well as the FIB-SEM, FIB-HIM, and gas permeability experiments on the core samples collected from the marine shales mentioned above. The conclusions are as follows: for the sealings of shale roof and floor, the regional cap rocks, roof, and floor provide sealing for shales due to physical property differences. For the self-sealing of shales, the second and third sub-members of Member I of the Wufeng Formation-Longmaxi Formation mainly develop clay mineral pores which are dominated by macropores with poor connectivity, while the first sub-member of Member I of the Wufeng Formation-Longmaxi Formation mainly develops organic-matter pores, which are dominated by micropores and mesopores with good connectivity. Owing to the connectivity difference, the second and third sub-members provide sealing for the first sub-member, while the methane adsorption effect of shales can inhibit large-scale shale gas migration as it decreases the 
gas permeability; thus, the organic-rich shales from the first sub-member of Member I of the Wufeng Formation-Longmaxi Formation provides sealing for itself.

Keywords: marine shale, roof and floor sealing, self-sealing, organic-matter pores, adsorption capacity

\section{INTRODUCTION}

As the economy in China has been developing fast in recent years, the demand for natural gas has increased vastly nationwide, while the domestic output of such a resource is far from sufficient for the demand. Therefore, all the major oil companies successively established four natural import channels, respectively, from the northeast, northwest, and southwest as well as by sea transportation. However, the gradually increasing import of and dependence on natural gas from abroad in recent years pose a mighty challenge against China's energy security (Curtis, 2002; Guo, 2016; Zou et al., 2017). Fortunately, China, similar to North America, has tremendous shale gas resources and has made significant progress in the exploration and exploitation of shale gas since 2009 (Guo, 2021).

As the geological theory of unconventional oil and gas was proposed, scientists have started researching on conditions for shale gas preservation (Guo et al., 2017). In the geological theory of conventional oil and gas, pelite is one of the most common cap rocks in the oil and gas field, and oil geologists have studied the sealing provided by pelite cap rocks for underlying reservoirs (Guo et al., 2020). Shales can be converted into source rocks when they satisfy certain conditions. When their thickness is bigger than the maximum distance between the hydrocarbon expulsion from the top and the bottom at the peak time of hydrocarbon generation of the shales, gas will be effectively sealed in them. Nevertheless, the geological theory of conventional oil and gas does not consider shales as reservoirs, and the research on vertical sealing from the perspective of pore characteristics is limited. The largest difference between shale gas and conventional gas in preservation conditions lies in the roof and floor conditions, as the roof and floor may feature the lithology of mudstone, shale, tight sandstone, or carbonatite, and its quality depends on the physical properties of the rock (Zou et al., 2015; Guo et al., 2016; Zou et al., 2016). The lithology of the roof and floor is critical to the preservation conditions of shale gas because the roof and floor with quality lithology in combination with a gas-preserving shale bed can form a fluid compartment, which effectively slows the outward migration of shale gas and thus makes it well preserved (Zou et al., 2017; He et al., 2019; Zou et al., 2020). On the contrary, the roof and floor with poor lithology provide weak sealing for fluids, easily dissipating oil or gas outward and thereby wasting shale gas reservoirs. In North America, the overlying and underlying strata of the Barnett shale reservoirs are both tight limestones, while the overlying strata of the Marcellus and the Haynesville shale reservoirs are shales and their underlying strata are tight limestone, all forming goodquality sealing strata which provide good preservation conditions and gas-bearing properties for shales (Zou et al., 2019).
A series of studies have been conducted on the shale roof and floor sealing and the shale self-sealing. Wei et al. (2017) concluded that the shale gas layer of the Wufeng-Longmaxi Formation is a typical "top-covered and bottom-clogged" type, which is favorable for shale gas preservation. It has sealing capacity for the following reasons: its floor strata are composed of nodular and regular limestone of the Linxiang and Baota Formations with dense lithology. Besides, the matrix porosity and permeability are generally less than $2 \%$ and $0.1 \times 10^{-3} \mu \mathrm{m}^{2}$, respectively. No fractures and sedimentary discontinuity exist. The marine mud shale of the Wufeng-Longmaxi Formation has a large specific surface area during the formation process of large amounts of shale gas, with copious hydrocarbon-friendly organic pores being formed. The shale gas is first adsorbed on the surface of these pores before it is stored in the pores or fractures of large diameters in a free state. Wei et al. (2017) and Cui et al. (2020) concluded that the top and bottom strata of the upper Ordovician Wufeng-lower Silurian Longmaxi shale gas formation are dense and exhibit low pore, low permeability characteristics. They also observed that the replacement and breakthrough pressures vary in different regions. For the top strata sample, both pressures were negatively correlated with the permeability: the lower the porosity degree and permeability, the stronger the replacement and breakthrough pressures. The gas-bearing capacity has a significant positive correlation with the microcosmic sealing capacity of the roof strata and a slight positive correlation with that of the floor strata, which means that the variances in the sealing capacity of the roof strata have more significant impact than those in the sealing capacity of the floor strata on the enrichment degree of shale gas (Cui et al., 2020).

Previous studies on the shale roof and floor sealing and shale self-sealing are not in-depth enough to study their formation mechanisms. By contrast, this article carried out research in this regard by taking JiaoYe1 well of the Jiaoshiba block located in the southeast of the Sichuan Basins in the upper Yangtze region in southern China as the study object. The Longmaxi Formation contains three members along the vertical direction, namely, Members I, II, and III from the bottom to the top. Based on the characteristics including rock colors, lithology, the combination of them both, and the combination of well logs, Member I of the Longmaxi Formation can be further divided into three sub-members, which are Sub-members I, II, and III from the bottom to the top, of which Sub-member I of Member I of the Wufeng Formation-Longmaxi Formation is currently the primary target strata of shale gas production in Sichuan Basins (Guo et al., 2016; Guo et al., 2017; Zhang et al., 2018a; Zhang et al., 2019a; Guo et al., 2020; Nie et al., 2020) (Figures 1-3). This article analyzed the mechanism of shale roof and floor sealing formation from the perspective of porosity, breakthrough pressure, and permeability, and marine shale self-sealing formation from the 


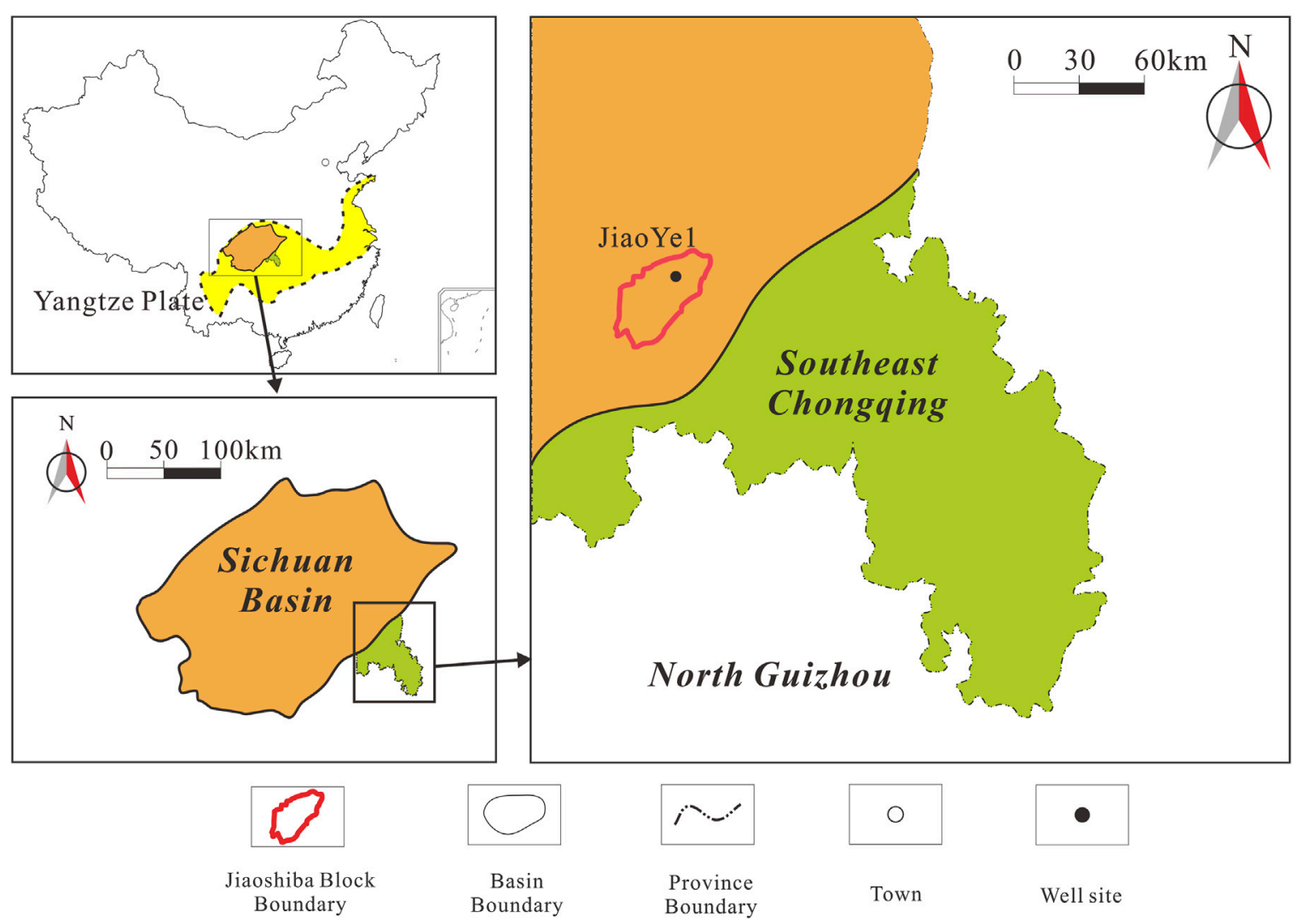

FIGURE 1 | Locations of the Jiaoshiba Block in the southeast of the Sichuan Basins in southern China and JiaoYe1 well. Modified from references (Zhang et al., 2018a; Zhang et al., 2019a; Nie et al., 2020).

perspective of porosity compositions, porosity structures, and adsorption effect.

\section{GEOLOGICAL SETTINGS}

\section{Sedimentary and Stratum Characteristics}

Previous studies have shown that (Mei et al., 2012; Wang et al., 2015; Mou et al., 2016; Zhang et al., 2019b; Wu et al., 2019; Zhang et al., 2020a; Ma et al., 2020) the upper Yangtze region turned into a cratonic basin after the Cathaysia plate extrusion during late Ordovician-early Silurian. The sedimentary strata of late Ordovician in the upper Yangtze region are named as the Wufeng formation, while the sedimentary strata of Early Silurian in the same region are named as the Longmaxi formation, which can be divided into Member I, II, and III from the bottom to top. The target stratum for the study in this article is Member I of the Wufeng-Longmaxi Formation. The shale in such a member features bipartite lithology: Sub-member I of Member I of the Wufeng Formation-Longmaxi Formation is dominated by black siliceous organic-rich shale, while Submembers II and III of Member I of the Longmaxi Formation is a combination of dark gray and silty shales, and siltstone.

\section{Tectonic Characteristics}

As evident from previous studies (Li et al., 1995; Li et al., 2002; Wang and Li, 2003; Zhang et al., 2017; Hu et al., 2018; Yang et al., 2019), the primitive continental crust in southern China was separated into two ancient plates in the early Mesoproterozoic period, of which one is the Yangtze plate and the other the Cathaysia plate. The two plates were stretching during the early Cambrian when large-scale transgressions occurred, leaving behind the sedimentation of a set of organic-rich shales that almost totally cover the plates. Afterward, the water body decreased; fine and silty shales gradually became coarse clasolites like siltstone and sandstone. When the Cathaysia late extruded the Yangtze plate in the Ordovician period, the water body further decreased, and the sedimentary system was changed from clasolites to carbonanites. The large-scale transgressions that happened in the late Ordovician-early Silurian changed it back to the sedimentary system of clasolites and left behind the sedimentation of a set of organic-rich shales in the deep-water shelter surrounded by the ancient continent. The Cathaysia plate started subduction toward the Yangtze plate and collided with it during the Cambrian-Silurian period. Then, the two plates merged with each other as the complete South China plate at the end of the Silurian period. 


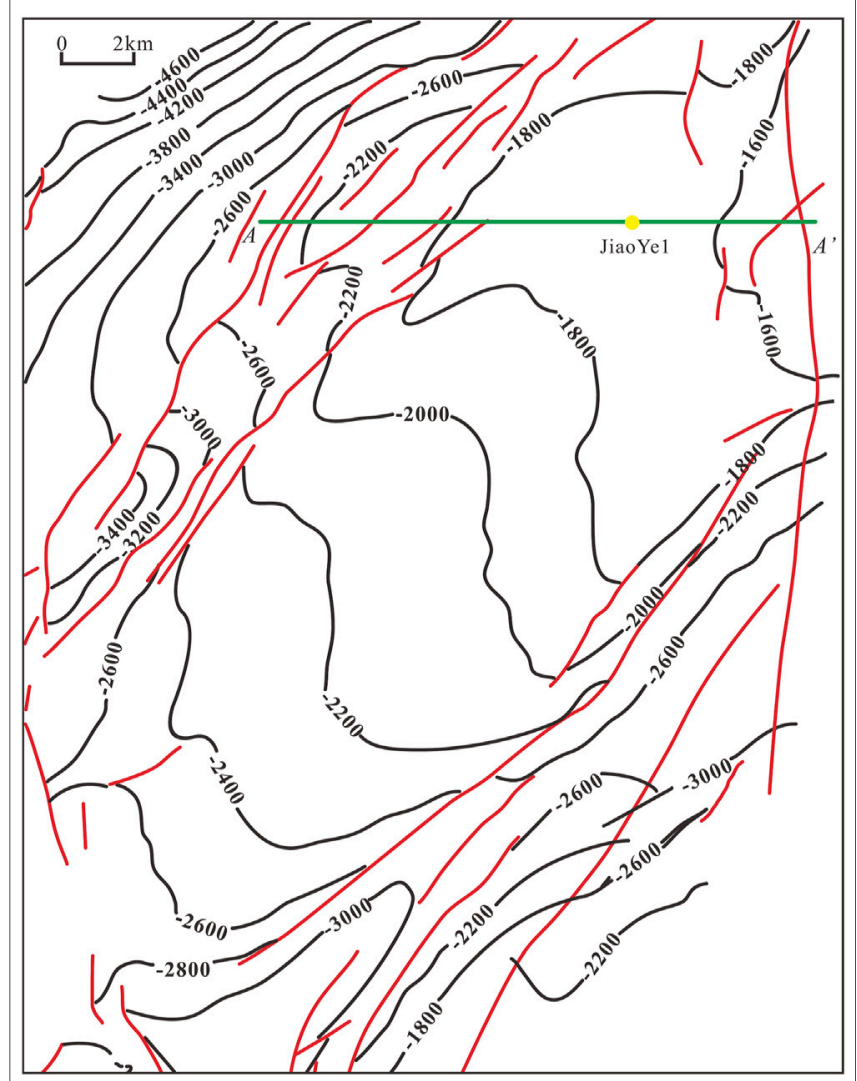

Legend
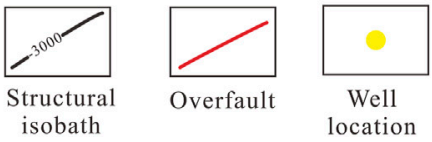

FIGURE 2 | Bottom structure map of Wufeng Formation in Jiaoshiba Block. Modified from references (Nie et al., 2020).

\section{SAMPLES, EXPERIMENTS, AND DATA SOURCES}

Member I of the Wufeng-Longmaxi Formation from the JiaoYe1 well was evenly sampled every $2 \mathrm{~m}$, and 42 pieces of cores were collected in total. The porosity was tested with a Poro PDP-200 porosity tester, the TOC content was tested with an OG-2000V carbon and sulfur analyzer, and the analysis of X- and clay minerals was conducted with a YST-I mineral analyzer. The data reported by Guo et al. (2016) were referred to for part of the test data (Guo et al., 2016). The data reported by Guo et al. (2017) and Jin et al. (2018) were referred to for the porosity test data of the gypsum rock from Members II and III of the Longmaxi Formation in the shale roof, and the Lower Triassic Jialingjiang Formation in the regional cap rocks as well as the Linxiang and Baota Formations in the shale floor (Guo et al., 2017; Jin et al., 2018). Part of the samples with different TOC contents was used for FIB-SEM (focused ion beam-scanning electron microscopy) experiments with a Helios NanoLab 660 apparatus and FIB-HIM (focused ion beam-helium ion microscopy) experiments with a Zeiss Orion NanoFab apparatus. Samples were collected from the stratum parallel to the $2,396 \mathrm{~m}$ organic-rich shales of the Longmaxi Formation Member I in Jiaoye No. well with a size of $2.5 \mathrm{~cm}$ (diameter) $\times 5 \mathrm{~cm}$ (length) each. They were used to measure core permeability with $\mathrm{N}_{2}, \mathrm{CH}_{4}$, and $\mathrm{CO}_{2}$, under the pressure of $5 \mathrm{MPa}$.

\section{RESULTS AND DISCUSSION}

\section{Sealing of Shale Roof and Floor}

As shown in Figure 4, JiaoYel well is a typical shale gas well in the Jiaoshiba Block of the eastern Sichuan region. The lithology of Member I of the Wufeng-Longmaxi Formation (referred to as Wu-Long Formation Member I hereinafter) is mainly a sedimentary shale under the deep-water shelter, that is, pure shales. The shale roof belongs to Member II of the Longmaxi Formation (referred to as Long Member II hereinafter) and Member III of the Longmaxi Formation (referred to as Long Member III hereinafter). The lithology of Long Member II is gray-dark gray siltstone, while that of Long Member III is gray-dark gray mudstone. The regional cap rocks are the gypsum rocks of the Lower Triassic Jialingjiang Formation, which is universally developed in the Sichuan Basins. The shale floor is the dark gray mud-

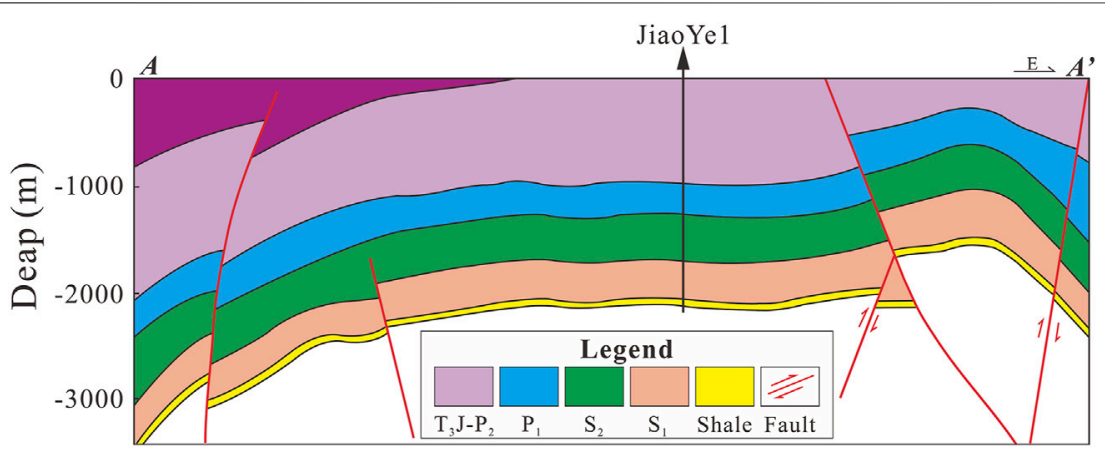

FIGURE 3 | Pass the JiaoYe1 well strata section in the Jiaoshiba block. Modified from references (Nie et al., 2020). 


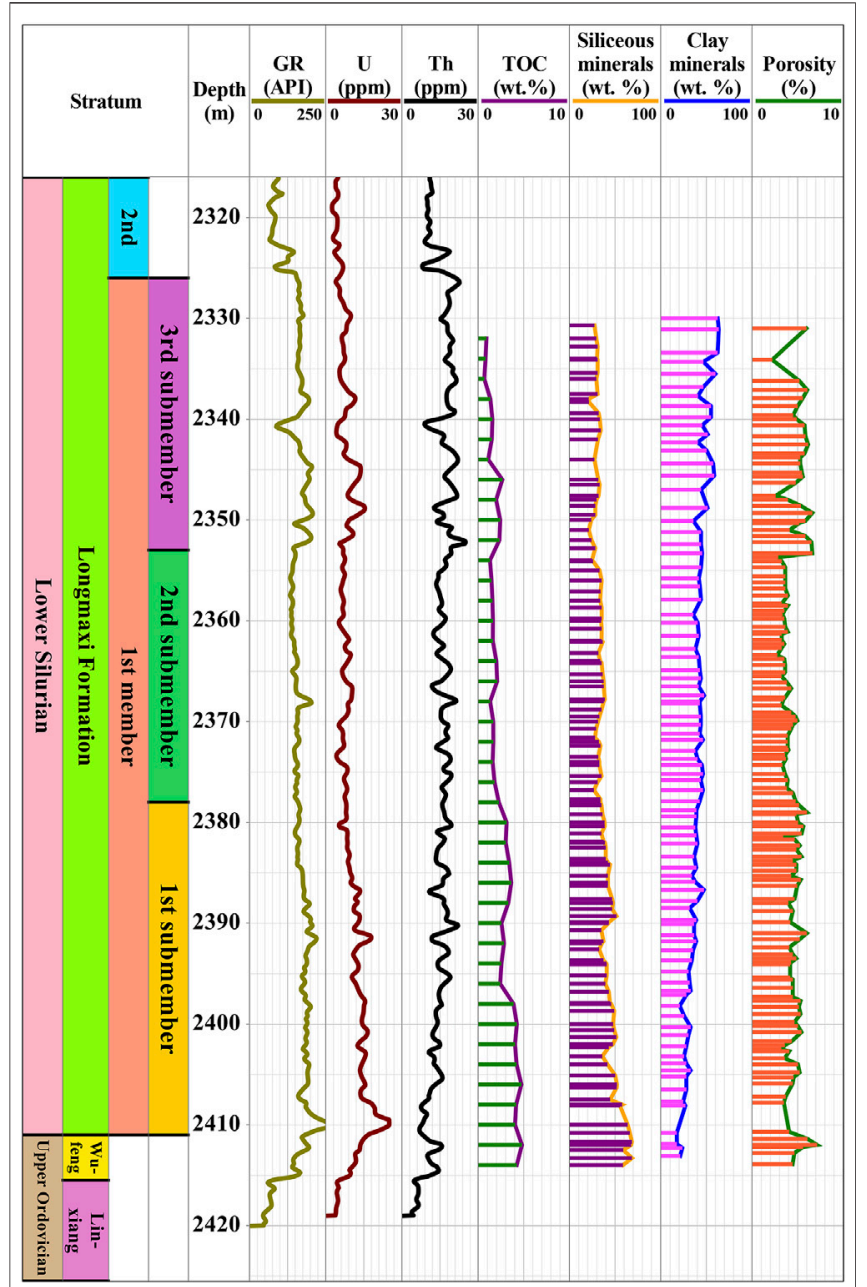

FIGURE 4 | Divisions of sub-members of JiaoYe1 well Longmaxi Formation Member I and analysis results of their mineral composition, TOC content, and porosity (refer to Figure $\mathbf{1}$ for the well location).

bearing nodular limestone of the upper Ordovician Linxiang Formation and the gray limestone of the Middle Ordovician Baota Formation (Wang et al., 2019; Wu et al., 2019; He et al., 2020).

As shown in Table 1, the Wu-Long Formation Member I shale of JiaoYe1 well and its roof and floor are successive sedimentations, with the latter featuring stable distribution, tight lithology, high thickness, high breakthrough pressure, and excellent sealing (Dong et al., 2018). The roof of the WuLong formation Member I shale is the gray-dark gray siltstone of Long Member II ( $10 \sim 35 \mathrm{~mm}$ thick in the Jiaoshiba region) and the gray-dark gray mudstone of Long Member III (100 $140 \mathrm{~mm}$ thick in the Jiaoshiba region), and the average porosity, permeability, and breakthrough pressure of the two members mentioned above are respectively $2.4 \%$, $0.0016 \times 10^{-3} \mu^{2}$, and $69.8 \sim 71.2 \mathrm{MPa}$ (Borjigin et al., 2017; Dong et al., 2018). Meanwhile, the floor of the $\mathrm{Wu}$ Long Formation Member I shale is the nodular limestone of the Lingxiang and Baota Formations $(30 \sim 40 \mathrm{~mm}$ thick in the
Jiaoshiba region with average porosity of $1.58 \%$ ), featuring a permeability of $0.0017 \times 10^{-3} \mu^{2}$ and a breakthrough pressure of $64.5 \sim 70.4 \mathrm{MPa}$ (Nie et al., 2019; Jin et al., 2020). The structural evolution simulation indicated that the gypsum rock on the top of JiaoYel well located at the higher part of the structure was destroyed $(5 \sim 0$ Ma before the present which is relatively late), while the section of the well located at the lower part of the structure still preserves the gypsum rock stratum that is $70 \sim 250 \mathrm{~mm}$ thick with porosity generally smaller than $2.00 \%$, and breakthrough pressure generally over $60 \mathrm{MPa}$ as well as excellent sealing performance. As the gypsum rock located in the deep part is highly plastic, its sealing performance for natural gas is further enhanced at the same time (Wu et al., 2018; Liu et al., 2019).

Based on the discussions above, the regional cap rocks (gypsum rock of the Lower Triassic Jialingjiang Formation), the roof (Long Member II gray-dark gray siltstone/dark gray lime shale and Long Member III gray-dark gray mudstone), and the floor (dark gray mud-bearing nodular limestone of the Linxiang Formation and gray limestone of the Baota Formation) provide sealing for the shale due to the difference in their physical properties.

\section{Self-Sealing of Shales}

The Difference in TOC Content, Mineral Composition, Pore Type, and Pore Structure

Table 2 shows the analyses on TOC content and mineral compositions, according to which the contents of brittle minerals and TOC decreased gradually from Sub-member I of the Wu-Long Formation Member I in the lower part (the average value is 65.9 and $3.58 \%$, respectively) to Sub-member III of the Long Member I in the upper part (the average values are 46.8 and $1.72 \%$, respectively). In contrast, the contents of clay minerals increased instead (from 34.1 to $53.2 \%$ ). The differences in mineral compositions and TOC content between all Wu-Long Formation Member I sub-members indicated different pore types. The shale pores can be classified as organic-matter pores, brittle mineral pores, and clay mineral pores based on their existing state.

Guo et al. (2016) quantitatively specified the contribution of every type of pores to the shale porosity with the help of physical models of porosity rocks. Due to the difference in mineral compositions and TOC content of shales, every submember contains different pore types (Table 2) (Guo et al., 2016; Guo et al., 2017; Guo et al., 2020). The percentage of clay mineral pores in the total porosity gradually increased from Sub-member I of the Wu-Long Formation Member I in the lower part to Sub-member III of the Long Member I in the upper part, while that of organic-matter pores in the total porosity gradually decreased at the same time (Guo et al., 2016; Guo et al., 2017; Guo et al., 2020).

In order to analyze the porosity structure characteristics of shales in different members, this article performed observation of the organic-matter pores in Sub-member I of JiaoYe1 well Long Member I and the clay mineral pores of Sub-member III of JiaoYe1 well Long Member I by FIB-SEM experiment. Sub- 
TABLE 1 | Lithology, porosity, thickness, and breakthrough pressure of JiaoYe1 well shale and its roof and floor, and regional cap rocks. Some data in the table are from references (Guo et al., 2016; Guo et al., 2017; Guo et al., 2020).

\begin{tabular}{|c|c|c|c|c|c|c|}
\hline Type & Description & Stratum & Lithology & $\begin{array}{l}\text { Average } \\
\text { porosity } \\
(\%)\end{array}$ & $\begin{array}{l}\text { Thickness } \\
\text { (m) }\end{array}$ & $\begin{array}{l}\text { Breakthrough } \\
\text { pressure } \\
\text { (MPa) }\end{array}$ \\
\hline \multirow[t]{6}{*}{ Combination } & $\begin{array}{l}\text { Regional cap } \\
\text { rocks }\end{array}$ & Lower Triassic Jialingjiang Formation & Gypsum rock & $<2.00$ & 70 & $>60$ \\
\hline & Shale roof & Member III of Lower Silurian Longmaxi Formation & $\begin{array}{l}\text { Gray-dark gray } \\
\text { mudstone }\end{array}$ & 2.40 & 128 & $69.8 \sim 71.2$ \\
\hline & & Member II of Lower Silurian Longmaxi Formation & Gray-dark gray siltstone & & 34 & \\
\hline & Shale & $\begin{array}{l}\text { Member I of Upper Ordovician Wufeng } \\
\text { Formation-Lower Silurian Longmaxi Formation }\end{array}$ & Shale & 4.77 & 89.5 & $\begin{array}{l}43.87 \text { (gas reservoir } \\
\text { pressure) }\end{array}$ \\
\hline & Shale floor & Upper Ordovician Linxiang Formation & $\begin{array}{l}\text { Dark gray mud-bearing } \\
\text { nodular limestone }\end{array}$ & 1.58 & $>30$ & $64.5 \sim 70.4$ \\
\hline & & Middle Ordovician Baota Formation & Gray limestone & & & \\
\hline
\end{tabular}

TABLE 2 | Mineral composition, TOC content, and percentage of various pore types of shales from Member I of the Wufeng Formation-Longmaxi Formation. Some data in the table are from references (Guo et al., 2016; Guo et al., 2017; Guo et al., 2020).

\begin{tabular}{|c|c|c|c|c|c|c|c|}
\hline \multirow[t]{2}{*}{ Stratum } & \multirow{2}{*}{$\begin{array}{c}\text { Brittle } \\
\text { mineral } \\
\text { content (\%) }\end{array}$} & \multirow{2}{*}{$\begin{array}{c}\text { Clay } \\
\text { mineral } \\
\text { content }(\%)\end{array}$} & \multirow{2}{*}{$\begin{array}{c}\text { TOC } \\
\text { content } \\
(\%)\end{array}$} & \multirow{2}{*}{$\begin{array}{c}\text { Total } \\
\text { porosity } \\
(\%)\end{array}$} & \multicolumn{3}{|c|}{ Percentage of every type of pore (\%) } \\
\hline & & & & & $\begin{array}{c}\text { Brittle } \\
\text { mineral } \\
\text { pore }\end{array}$ & $\begin{array}{c}\text { Clay } \\
\text { mineral } \\
\text { pore }\end{array}$ & $\begin{array}{c}\text { Organic-matter } \\
\text { pore }\end{array}$ \\
\hline Sub-member III of Long Member I & $\begin{array}{c}37.2 \sim 63.3 \\
\quad / 46.8\end{array}$ & $\begin{array}{c}36.7 \sim 62.8 \\
\quad / 53.2\end{array}$ & $\begin{array}{c}0.6 \sim 2.93 \\
/ 1.72\end{array}$ & $\begin{array}{c}3.44 \sim 7.13 \\
\quad / 5.36\end{array}$ & $\begin{array}{c}3 \sim 6.6 \\
/ 5\end{array}$ & $\begin{array}{c}53 \sim 88 \\
\quad / 71\end{array}$ & $\begin{array}{c}8.7 \sim 41 \\
/ 24\end{array}$ \\
\hline Sub-member II of Long Member I & $\begin{array}{c}43.7 \sim 66.6 \\
\quad / 58.5\end{array}$ & $\begin{array}{l}33.4 \sim 46.3 \\
\quad / 41.5\end{array}$ & $\begin{array}{c}1.39 \sim 2.46 \\
\quad / 1.81\end{array}$ & $\begin{array}{c}2.49 \sim 4.72 \\
/ 3.72\end{array}$ & $\begin{array}{c}4.9 \sim 8 \\
16\end{array}$ & $\begin{array}{c}57 \sim 70 \\
/ 64\end{array}$ & $\begin{array}{c}24 \sim 37 \\
\quad / 30\end{array}$ \\
\hline $\begin{array}{l}\text { Sub-member I of Wu-Long Formation } \\
\text { Member I }\end{array}$ & $\begin{array}{l}53 \sim 83.4 \\
\quad / 65.9\end{array}$ & $\begin{array}{c}16.6 \sim 47 \\
\quad / 34.1\end{array}$ & $\begin{array}{c}1.06 \sim 5.28 \\
/ 3.58\end{array}$ & $\begin{array}{l}2.83 \sim 5.89 \\
\quad / 4.60\end{array}$ & $\begin{array}{c}4.4 \sim 10 \\
/ 6\end{array}$ & $\begin{array}{c}17 \sim 77 \\
/ 43\end{array}$ & $\begin{array}{c}18 \sim 76 \\
\quad / 51\end{array}$ \\
\hline
\end{tabular}

member I of Long Member I was found to contain a large number of organic-matter pores with big diameters (micropores, mesopores, and macropores <200 nm), of which most are elliptical ones (A of Figure 5). Meanwhile, Sub-member III of Long Member I was found to contain clay mineral pores fewer than organic-matter pores in quantity, but bigger in diameter (macropores of $200 \mathrm{~nm} \sim 1 \mu \mathrm{m}$ ), and most of the pores were in irregular shapes.

The internal three-dimensional structure of the pores was further observed by FIB-HIM experiments. The FIB-HIM experiment was performed on samples at a depth close to that of the FIB-SEM sample, and it was found through observation that the organic-matter pores of Sub-member I of JiaoYe1 well Long Member I contain big pores with small ones inside them. With this type of "small pores inside big pores" characteristic, not only organic-matter reservoir space and specific surface area are enlarged but also the seepage channels are provided for shale gas, thus enhancing organicmatter connectivity (B of Figure 5) (Ji et al., 2014; Ji et al., 2015; Wang et al., 2016a; Wang et al., 2016b; Ji et al., 2016; Tang et al., 2017). The pores developed in the clay mineral pores of Sub-member III of Long Member I are more separated and fewer in quantity with poor reservoir capacity and connectivity ( $\mathrm{D}$ of Figure 5 ).

It can be concluded from the previous discussion that the change in TOC content and mineral compositions between Sub- members II and III of Long Member I and Sub-member I of the $\mathrm{Wu}$-Long Formation Member I caused the variation in porosity types and structures and the difference in connectivity, which causes Sub-members II and III of Long Member I to form sealing for Sub-member I of Long Member I.

\section{Adsorption Effect}

Samples with a dimension of $2.5 \mathrm{~cm}$ (diameter) $\times 5 \mathrm{~cm}$ (length) were collected from the organic-rich shales of JiaoYe1 well Long Member I at 2,396 $\mathrm{mm}$ along the parallel direction with the strata. These samples were measured for the flow velocity and gas permeability of the cores with $\mathrm{N}_{2}, \mathrm{CH}_{4}$, and $\mathrm{CO}_{2}$, respectively, under the pressure of $5 \mathrm{MPa}$ (refer to Table 3 and Figure 6 for the measurement results).

The gas molecule adsorption by shales created the gas slippage effect (Klinkenberg effect) in the seepage channel (Zhang et al., 2019c; Zhang et al., 2020b; Liu et al., 2021a; Liu et al., 2021b); that is, the flow velocity of gas molecules in the channel center is higher than that close to the channel wall, and the closer gas molecules to the channel wall, the slower their flow velocity (Huang et al., 2020; Zhang et al., 2019d; Zhang et al., 2020c; Wang et al., 2020; Zuo et al., 2019; Xia et al., 2020; Gao, 2021; Yu et al., 2022). The gas adsorption capacity of shales can be ranked as $\mathrm{CO}_{2}>\mathrm{CH}_{4}>\mathrm{N}_{2}$, while the rank is reversed regarding the flow velocity and permeability of those gases in shales as $\mathrm{CO}_{2}<\mathrm{CH}_{4}<\mathrm{N}_{2}$ (Figure 7). It 

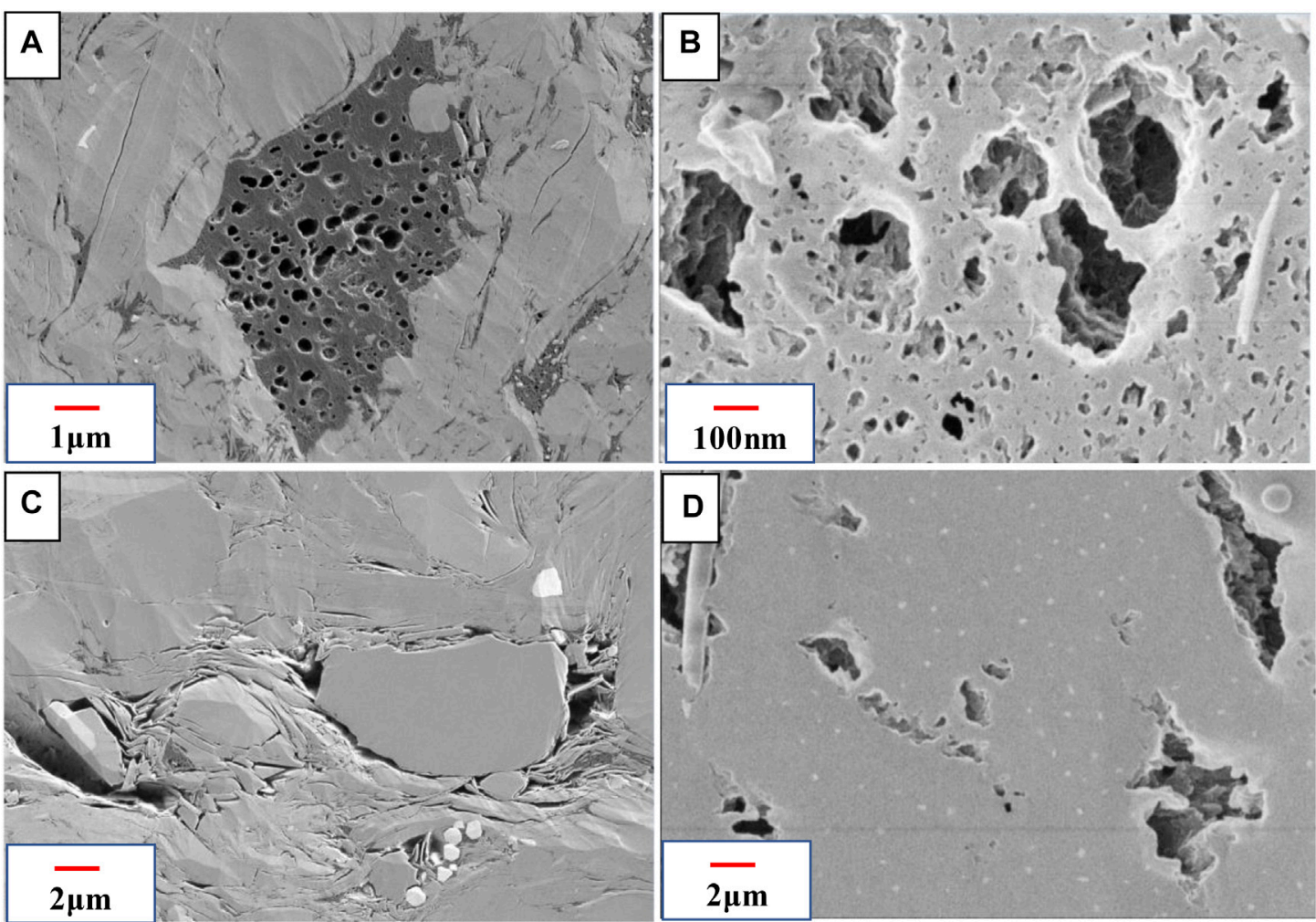

FIGURE 5 | FIB-SEM and FIB-HIM Images of Shales Respectively from Sub-members I and III of JiaoYe1 Well Wu-Long Formation. Organic-matter Pores of Submember I of JiaoYe1 Well Wu-Long Formation Member I, 2405 m: (A) FIB-SEM Image, (B) FIB-HIM Image. Clay Mineral Pores of Sub-member III of JiaoYe1 Well WuLong Formation Member I, 2342 m: (C) FIB-SEM Image, (D) FIB-HIM Image.

TABLE 3 | Flow velocity and gas permeability tests on shales with $\mathrm{N}_{2}, \mathrm{CH}_{4}$, and $\mathrm{CO}_{2}$.

\begin{tabular}{lccc} 
Type of gas & Pressure (MPa) & Flow velocity $(\mathbf{m l} / \mathbf{s})$ & Permeability (md) \\
\hline $\mathrm{N}_{2}$ & 5 & 1.7375 & 0.019256 \\
$\mathrm{CH}_{4}$ & 5 & 1.2285 & 0.012783 \\
$\mathrm{CO}_{2}$ & 5 & 1.0083 & 0.012173
\end{tabular}

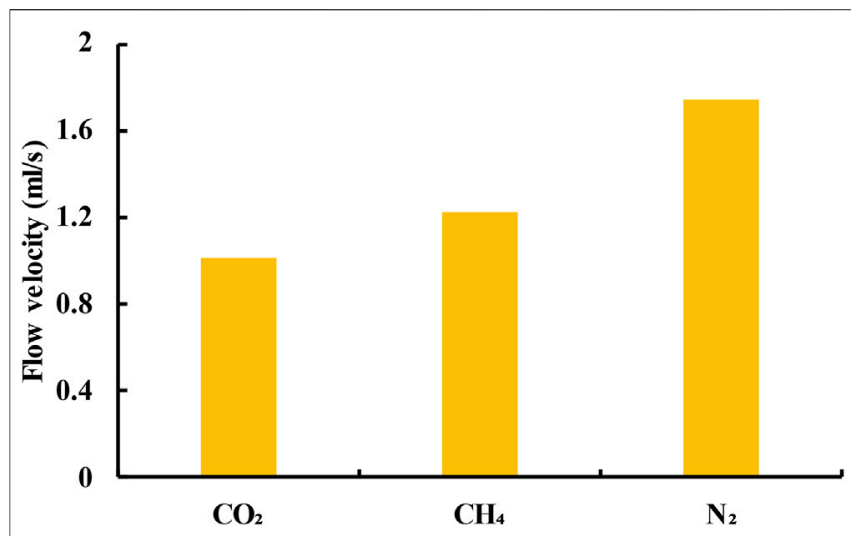

FIGURE 6 | Comparison of three different gas flow rates. The flow velocity of gases in shales is $\mathrm{CO}_{2}<\mathrm{CH}_{4}<\mathrm{N}_{2}$. indicates that the gas slippage effect is more obvious, the gas molecule flow velocity is slower, and the permeability is more decreased when the gas adsorption capacity of shales is higher (Wang et al., 2017; Zhang et al., 2018b). In organic-rich shales, the higher the quantity of adsorbed methane, the more evident the gas slippage effect; the higher the TOC content, the thicker the organic-rich shales, resulting in lower shale permeability and providing better conditions for shale gas preservation.

It can be concluded from the previous discussion that higher TOC content and adsorption capacity of shales lead to narrower effective pore throat and lower permeability, thus resulting in better self-sealing performance. Meanwhile, the self-sealing of shales can also be enhanced when the thickness of organic-rich shales is increased, and thereby, their adsorption quantity rises.

\section{Formation Mechanism}

Based on the above discussion, this article summarizes the Forming model of sealing of roof and floor and self-sealing of shale of Wufeng Formation-Longmaxi Formation as shown below (Figure 8). The regional cap, the roof, and floor strata of the shale (Figures 8A,D) have much lower porosities and higher breakthrough pressure than the shale (Figures $\mathbf{8 B}, \mathbf{C}$ ), and they are closed to the shale due to the difference 


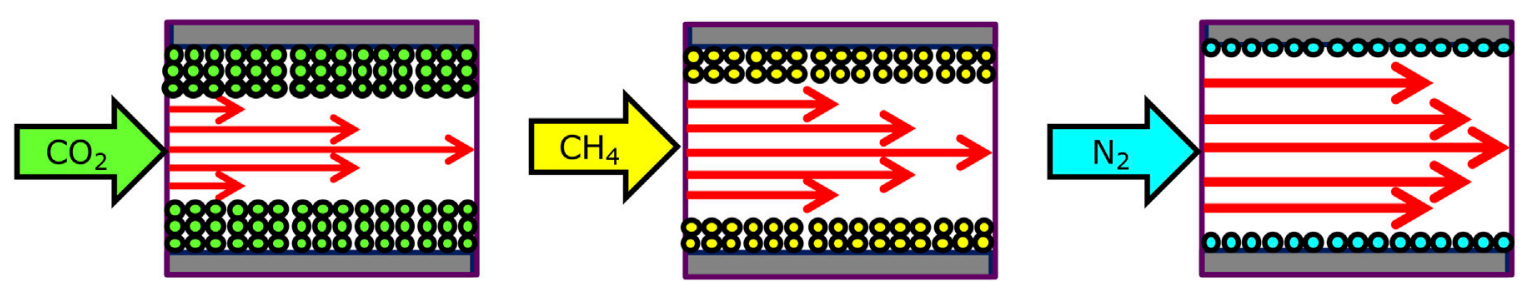

FIGURE 7 | Schematic diagram of the effect of adsorption on gas flow velocity and permeability in shale.

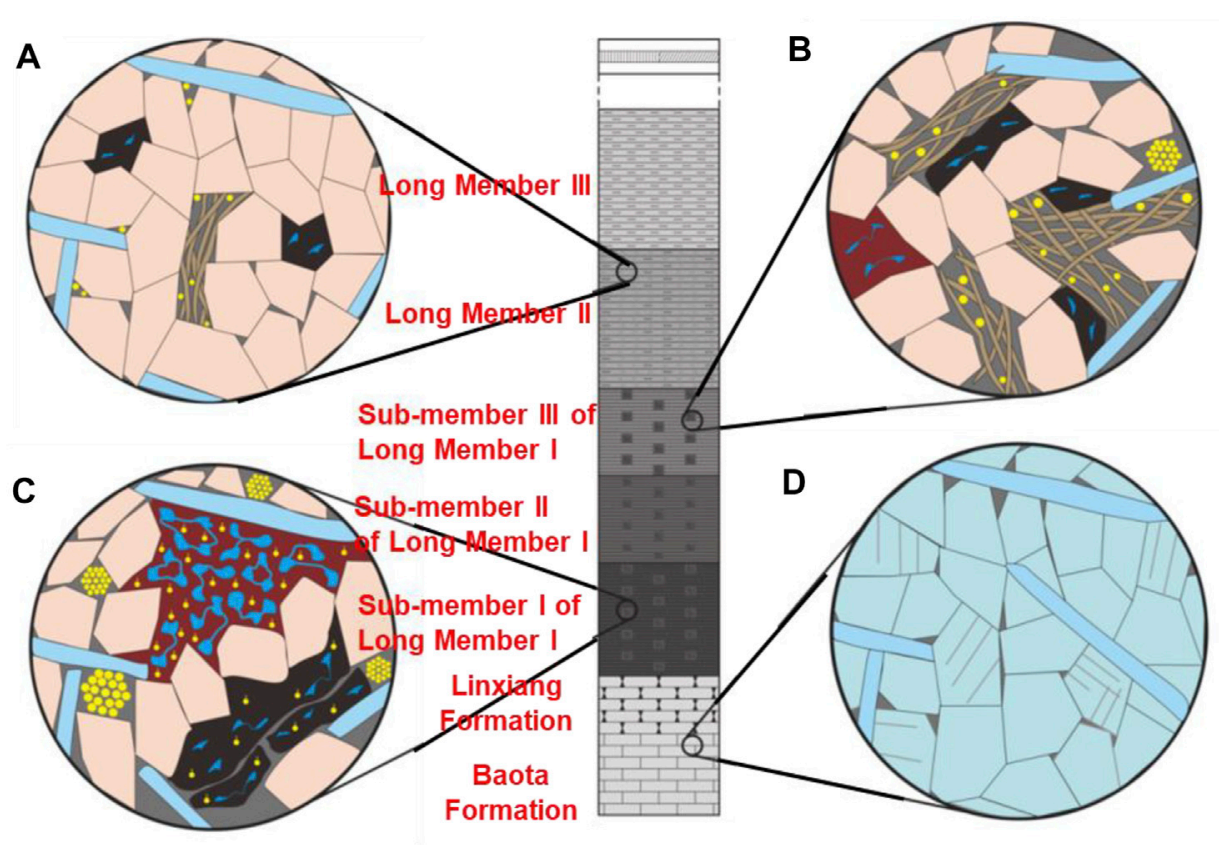

legend

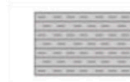

Grey mudstone Argillaceous mudstone siltstone

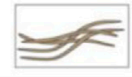

Clay minerals
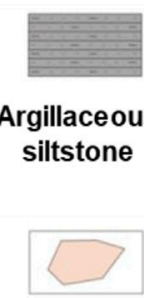

Quartz

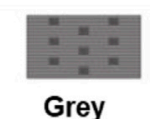

siliceous

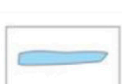

Feldspar

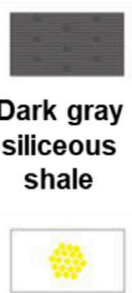

Pyrite

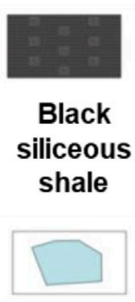

Carbonate minerals

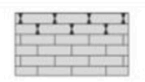

Nodular

limestone

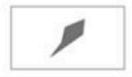

Inorganic pore
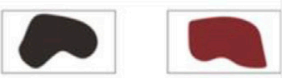

Kerogen Tar pitch

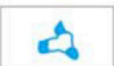

Organic matter Shale gas

FIGURE 8 | Forming model of the sealing of roof and floor and self-sealing of shale of Wufeng-Longmaxi Formation.

in physical properties. For the shale, the second and third subsections of section I of the Longmaxi Formation mainly develop clay mineral pores, which are mainly of macropores with poor connectivity (Figure 8B); the first subsection of section I of the Wufeng Formation-Longmaxi Formation mainly develops organic matter pores, which are primarily micro and medium pores with good connectivity (Figure 8C).
The connectivity difference leads to the second and third subsections forming sealing capacity to the first subsections. The adsorption of methane by the organic-rich shale in the first subsection of the Wufeng Formation-Longmaxi Formation section I (Figure 8C) will inhibit the large-scale transport of shale gas, thus causing the organic-rich shale to form its self-sealing capacity. 


\section{CONCLUSION}

In this article, Member I of the Upper Ordovician Wufeng Formation-Lower Silurian Longmaxi Formation from the Yangtze region was used as the case for the study, and the marine shales from Member I of the Wufeng Formation-Longmaxi Formation of the Jiaoshiba Block in the Sichuan Basins were selected for detailed analyses. The analyses of TOC content, mineral compositions, and porosity, as well as the experiments of FIB-SEM, FIB-HIM, and gas permeability, were then conducted on the core samples from the shale gas exploration well for the study on the formation mechanism of shale roof and floor sealing and shale self-sealing, and it was concluded as follows:

1) Regarding shale roof and floor sealing: The regional cap rocks (gypsum rocks of the Lower Triassic Jialingjiang Formation), the roof (gray-dark gray siltstone/dark gray lime shales of Member II of the Longmaxi Formation, and gray-dark gray mudstone of Member III of the Longmaxi Formation), and the floor (dark gray mudbearing nodular limestone of the Linxiang Formation and gray limestone of the Baota Formation) together had sealing effects on the shales of Member I of the Wufeng Formation-Longmaxi Formation due to the differences in physical properties.

2) For shale self-sealing: Sub-members II and III of Member I of the Longmaxi Formation are different from Sub-member I of Member I of the Wufeng-Longmaxi Formation in pore types: clay pores dominated by macropores with poor connectivity were mainly developed in Sub-members II and III, while organic-matter pores dominated by micropores and mesopores with excellent connectivity were developed in Sub-member I of Member I of the Wufeng-Longmaxi Formation. Thanks to the difference in connectivity, Sub-members II and III together formed sealing for Sub-member I.

3) The methane adsorption effect of shales decreased the permeability and inhibited the massive migration of shale gas. As a result of the adsorption effect, the organic-rich shales

\section{REFERENCES}

Borjigin, T., Shen, B., Yu, L., Yang, Y., Zhang, W., Tao, C., et al. (2017). Mechanisms of Shale Gas Generation and Accumulation in the Ordovician Wufeng-Longmaxi Formation, Sichuan Basin, SW China. Pet. exploration Dev. 44 (1), 69-78. 2017. doi:10.1016/s1876-3804(17)30009-5

Cui, Z., Yang, W., Wang, Q., Zuo, R., Cai, J., Cui, Z., et al. (2020). Sealing Property of Roof and Floor of Wufeng Formation-Longmaxi Formation and its Influence on Shale Gas Differential Enrichment in Sichuan Basin and its Surrounding Areas. Mar. oil gas Geology. 25 (3), 243-252. (in Chinese with English abstract).

Curtis, J. B. (2002). Fractured Shale-Gas Systems. AAPG Bull. 86 (11), 1921-1938. doi:10.1306/61eeddbe-173e-11d7-8645000102c1865d

Dong, D., Shi, Z., Guan, Q., Jiang, S., Zhang, M., Zhang, C., et al. (2018). Progress, Challenges and Prospects of Shale Gas Exploration in the Wufeng-Longmaxi Reservoirs in the Sichuan Basin. Nat. Gas Industry B 5 (5), 415-424. 2018. doi:10.1016/j.ngib.2018.04.011 from Sub-member I of Member I of the Wufeng-Longmaxi Formation can seal themselves.

\section{DATA AVAILABILITY STATEMENT}

The original contributions presented in the study are included in the article/Supplementary Material; further inquiries can be directed to the corresponding author.

\section{AUTHOR CONTRIBUTIONS}

PW, YL, XDY, ZC, ZL, XJY, and PL contributed to conception and design of the study. FH, LT, and YY organized the database. YZ performed the statistical analysis. ZZ wrote the first draft of the manuscript. KZ, YS, ZJ, and SJ wrote sections of the manuscript. All authors contributed to manuscript revision, and read and approved the submitted version.

\section{FUNDING}

This study was supported by the Foundation of State Key Laboratory of Petroleum Resources and Prospecting, China University of Petroleum, Beijing (No. PRP/open-2107), the National Natural Science Foundation of China (No. 42102192, 42130803, and 42072174), the open fund of Key Laboratory of Tectonics and Petroleum Resources (China University of Geosciences), the Ministry of Education, Wuhan (TPR-202007), the open fund from the State Key Laboratory of Shale Oil and Gas Enrichment Mechanisms and Effective Development (G5800-20-ZS-KFGY012), and the Science and Technology Cooperation Project of the CNPC-SWPU Innovation Alliance.

\section{ACKNOWLEDGMENTS}

We sincerely appreciate all reviewers and the handling editor for their critical comments and constructive suggestions.

Gao, F. (2021). Influence of Hydraulic Fracturing of strong Roof on MiningInduced Stress Insight from Numerical Simulation. J. Mining Strata Control. Eng. 3 (2), 023032.

Guo, X., Hu, D., Wei, Z., Li, Y., and Wei, X. (2016). Discovery and Exploration of Fuling Shale Gas Field. China Pet. Exploration 21 (3), 24-37. (in Chinese with English abstract).

Guo, X., Hu, D., Li, Y., Wei, Z., Wei, X., and Liu, Z. (2017). Geological Factors Controlling Shale Gas Enrichment and High Production in Fuling Shale Gas Field. Pet. Exploration Dev. 44, 513-523. doi:10.1016/s1876-3804(17)30060-5

Guo, X., Li, Y., Borjigen, T., Wang, Q., Yuan, T., Shen, B., et al. (2020). Hydrocarbon Generation and Storage Mechanisms of Deep-Water Shelf Shales of Ordovician Wufeng Formation-Silurian Longmaxi Formation in Sichuan Basin, China. Pet. Exploration Dev. 471, 204-213. doi:10.1016/ s1876-3804(20)60019-2

Guo, T. (2016). Key Geological Issues and Main Controls on Accumulation and Enrichment of Chinese Shale Gas. Pet. Exploration Dev. 43 (3), 317-326. (in Chinese with English abstract). doi:10.1016/s1876-3804(16)30042-8 
Guo, T. (2021). Geological Characteristics and Exploration Prospect of Carbonate Source Rock Gas in Sichuan Basin. J. Southwest Pet. Univ. (Science Tech. Edition) 43 (1), 1. (in Chinese with English abstract).

He, Z., Li, S., Nie, H., Yuan, Y., and Wang, H. (2019). The Shale Gas "sweet Window": "The Cracked and Unbroken" State of Shale and its Depth Range. Mar. Pet. Geology. 101, 334-342. doi:10.1016/j.marpetgeo.2018.11.033

He, Z., Nie, H., Li, S., Luo, J., Wang, H., and Zhang, G. (2020). Differential Enrichment of Shale Gas in Upper Ordovician and Lower Silurian Controlled by the Plate Tectonics of the Middle-Upper Yangtze, south China. Mar. Pet. Geology. 118, 104357. 2020. doi:10.1016/j.marpetgeo.2020.104357

Hu, M., Huang, W., and Li, J. (2018). Effects of Structural Characteristics on the Productivity of Shale Gas wells: A Case Study on the Jiaoshiba Block in the Fuling Shale Gasfield, Sichuan Basin. Nat. Gas Industry B 5 (2), 139-147. doi:10.1016/j.ngib.2018.02.001

Huang, H., Li, R., Jiang, Z., Li, J., and Chen, L. (2020). Investigation of Variation in Shale Gas Adsorption Capacity with Burial Depth: Insights from the Adsorption Potential Theory. J. Nat. Gas Sci. Eng. 73, 103043. 2020. doi:10.1016/j.jngse.2019.103043

Ji, W., Song, Y., Jiang, Z., Wang, X., Bai, Y., and Xing, J. (2014). Geological Controls and Estimation Algorithms of Lacustrine Shale Gas Adsorption Capacity: a Case Study of the Triassic Strata in the Southeastern Ordos Basin, China. Int. J. Coal Geology. 134-135 (135), 61-73. doi:10.1016/j.coal.2014.09.005

Ji, W., Song, Y., Jiang, Z., Chen, L., Li, Z., Yang, X., et al. (2015). Estimation of marine Shale Methane Adsorption Capacity Based on Experimental Investigations of Lower Silurian Longmaxi Formation in the Upper Yangtze Platform, South China. Mar. Pet. Geology. 68, 94-106. doi:10.1016/j.marpetgeo.2015.08.012

Ji, W., Song, Y., Jiang, Z., Meng, M., Liu, Q., Chen, L., et al. (2016). Fractal Characteristics of Nano-Pores in the Lower Silurian Longmaxi Shales from the Upper Yangtze Platform, South China. Mar. Pet. Geology. 78, 88-98. doi:10.1016/j.marpetgeo.2016.08.023

Jin, Z., Nie, H., Liu, Q., Zhao, J., and Jiang, T. (2018). Source and Seal Coupling Mechanism for Shale Gas Enrichment in Upper Ordovician Wufeng Formation - Lower Silurian Longmaxi Formation in Sichuan Basin and its Periphery. Mar. Pet. Geology. 97, 78-93. 2018. doi:10.1016/j.marpetgeo.2018.06.009

Jin, Z., Nie, H., Liu, Q., Zhao, J., Wang, R., Sun, C., et al. (2020). Coevolutionary Dynamics of Organic-Inorganic Interactions, Hydrocarbon Generation, and Shale Gas Reservoir Preservation: A Case Study from the Upper Ordovician Wufeng and Lower Silurian Longmaxi Formations, Fuling Shale Gas Field, Eastern Sichuan Basin. Geofluids 2020, doi:10.1155/2020/6672386

Li, Z.-X., Zhang, L., and Powell, C. M. (1995). South China in Rodinia: Part of the Missing Link between Australia-East Antarctica and Laurentia. Geol 23 (5), 407-410. doi:10.1130/0091-7613(1995)023<0407:scirpo >2.3.co;2

Li, Z.-X., Li, X.-h., Zhou, H., and Kinny, P. D. (2002). Grenvillian continental Collision in South China: New SHRIMP U-Pb Zircon Results and Implications for the Configuration of Rodinia. Geol 30 (2), 163-166. doi:10.1130/00917613(2002)030<0163:gccisc $>2.0 . c 0 ; 2$

Liu, X., Jiang, Z., Zhang, K., Song, Y., Jiang, L., Jiang, S., et al. (2019). Mechanism Analysis of Organic Matter Enrichment of Upper Ordovician-Lower Silurian Shale in the Upper Yangtze Area: Taking Jiaoye-1 Well in the Jiaoshiba Block as an Example. Geofluids 2019, 2019. doi:10.1155/2019/5806023

Liu, B., He, S., Meng, L., Fu, X., Gong, L., and Wang, H. (2021). Sealing Mechanisms in Volcanic Faulted Reservoirs in Xujiaweizi Extension, Northern Songliao Basin, Northeastern China. AAPG Bull. 2021 (20), 210-315. doi:10.1306/03122119048

Liu, B., Sun, J., Zhang, Y., He, J., Fu, X., Yang, L., et al. (2021). Reservoir Space and Enrichment Model of Shale Oil in the First Member of Cretaceous Qingshankou Formation in the Changling Sag, Southern Songliao Basin, NE China. Pet. Exploration Dev. 48 (3), 608-624. 2021. doi:10.1016/s1876-3804(21)60049-6

Ma, X., Xie, J., Yong, R., and Zhu, Y. (2020). Geological Characteristics and High Production Control Factors of Shale Gas Reservoirs in Silurian Longmaxi Formation, Southern Sichuan Basin, SW China. Pet. Exploration Dev. 47 (5), 841-855. doi:10.1016/s1876-3804(20)60105-7

Mei, L., Deng, D., Shen, C., and Liu, Z. (2012). Tectonic Dynamics and marine Hydrocarbon Accumulation of Jiangnan-Xuefeng Uplift. Geol. Sci. Tech. Inf. 31 (5), 85-93. 2012(in Chinese with English abstract).

Mou, C., Wang, X., Wang, Q., Zhou, K., Liang, W., Ge, X., et al. (2016). Relationship between Sedimentary Facies and Shale Gas Geological Conditions of the Lower Silurian Longmaxi Formation in Southern Sichuan
Basin and its Adjacent Areas. J. Palaeogeogr. 18 (3), 457-472. (in Chinese with English abstract).

Nie, H., Sun, C., Liu, G., Du, W., and He, Z. (2019). Dissolution Pore Types of the Wufeng Formation and the Longmaxi Formation in the Sichuan Basin, south China: Implications for Shale Gas Enrichment. Mar. Pet. Geology. 101, 243-251. 2019. doi:10.1016/j.marpetgeo.2018.11.042

Nie, H., Zhang, B., and Liu, G. (2020). Geological Factors Contributing to High Shale Gas Yield in the Wufeng-Longmaxi Fms of Sichuan Basin: A Case Study of Well JY6-2HF in Fuling Shale Gas Field. Oil Gas Geology. 41 (3), 463-473. (in Chinese with English abstract).

Tang, X., Jiang, Z., Jiang, S., Cheng, L., and Zhang, Y. (2017). Characteristics and Origin of In-Situ Gas Desorption of the Cambrian Shuijingtuo Formation Shale Gas Reservoir in the Sichuan Basin, China. Fuel 187, 285-295. 2017. doi:10.1016/j.fuel.2016.09.072

Wang, J., and Li, Z. (2003). History of Neoproterozoic Rift Basins in South China: Implications for Rodinia Break-Up. Precambrian Res. 122 (1/4), 141-158. doi:10.1016/s0301-9268(02)00209-7

Wang, Y., Dong, D., Li, X., Huang, J., Wang, S., and Wu, W. (2015). Stratigraphic Sequence and Sedimentary Characteristics of Lower Silurian Longmaxi Formation in the Sichuan Basin and its Peripheral Areas. Nat. Gas Industry 35 (3), 12-21. (in Chinese with English abstract).

Wang, P., Jiang, Z., Chen, L., Yin, L., Li, Z., Zhang, C., et al. (2016). Pore Structure Characterization for the Longmaxi and Niutitang Shales in the Upper Yangtze Platform, South China: Evidence from Focused Ion Beam-He Ion Microscopy, Nano-Computerized Tomography and Gas Adsorption Analysis. Mar. Pet. Geology. 77, 1323-1337. 2016. doi:10.1016/j.marpetgeo.2016.09.001

Wang, P., Jiang, Z., Ji, W., Zhang, C., Yuan, Y., Chen, L., et al. (2016). Heterogeneity of Intergranular, Intraparticle and Organic Pores in Longmaxi Shale in Sichuan Basin, South China: Evidence from SEM Digital Images and Fractal and Multifractal Geometries. Mar. Pet. Geology. 72, 122-138. 2016. doi:10.1016/ j.marpetgeo.2016.01.020

Wang, P., Jiang, Z., Yin, L., Chen, L., Li, Z., Zhang, C., et al. (2017). Lithofacies Classification and its Effect on Pore Structure of the Cambrian marine Shale in the Upper Yangtze Platform, South China: Evidence from FE-SEM and Gas Adsorption Analysis. J. Pet. Sci. Eng. 156 (2017), 307-321. doi:10.1016/ j.petrol.2017.06.011

Wang, R., Hu, Z., Long, S., Liu, G., Zhao, J., Dong, L., et al. (2019). Differential Characteristics of the Upper Ordovician-Lower Silurian Wufeng-Longmaxi Shale Reservoir and its Implications for Exploration and Development of Shale Gas In/around the Sichuan Basin. Acta Geologica Sinica - English Edition 93 (3), 520-535. 2019. doi:10.1111/1755-6724.13875

Wang, J., Zhang, C., Zheng, D., Song, W., and Ji, X. (2020). Stability Analysis of Roof in Goaf Considering Time Effect. J. Mining Strata Control. Eng. 2 (1), 013011.

Wei, X., Li, Y., Wei, Z., Liu, R., Yu, G., and Wang, Q. (2017). Effects of Preservation Conditions on Enrichment and High Yield of Shale Gas in Sichuan Basin and its Periphery. Pet. Geology. Exp. 39 (2), 147-153. (in Chinese with English abstract).

Wu, L., Lu, Y., Jiang, S., Liu, X., and He, G. (2018). Effects of Volcanic Activities in Ordovician Wufeng-Silurian Longmaxi Period on Organic-Rich Shale in the Upper Yangtze Area, South China. Pet. Exploration Dev. 45 (5), 862-872. 2018. doi:10.1016/s1876-3804(18)30089-2

Wu, J., Liang, C., Hu, Z., Yang, R., Xie, J., Wang, R., et al. (2019). Sedimentation Mechanisms and Enrichment of Organic Matter in the Ordovician Wufeng Formation-Silurian Longmaxi Formation in the Sichuan Basin. Mar. Pet. Geology. 101, 556-565. doi:10.1016/j.marpetgeo.2018.11.025

Xia, Y., Lu, C., Yang, G., Su, S., Pang, L., Ding, G., et al. (2020). Experimental Study on Axial Fracture Cutting and Fracturing of Abrasive Jet in Hard Roof Hole. J. Mining Strata Control. Eng. 2 (3), 033522.

Yang, Y., Chen, C., Wen, L., Chen, X., Liang, H., Liu, R., et al. (2019). Characteristics of Buried Structures in Northern Longmenshan Mountains and its Significance to Oil and Gas Exploration in the Sichuan Basin. Nat. Gas Industry B 6 (2), 175-182. 2019. doi:10.1016/j.ngib.2018.08.003

Yu, X., Bian, J., and Liu, C. (2022). Determination of Energy Release Parameters of Hydraulic Fracturing Roof Near Goaf Based on Surrounding Rock Control of Dynamic Pressure Roadway. J. Mining Strata Control. Eng. 4 (1), 013016.

Zhang, K., Jiang, Z., Yin, L., Gao, Z., Wang, P., Song, Y., et al. (2017). Controlling Functions of Hydrothermal Activity to Shale Gas Content-Taking Lower Cambrian in Xiuwu Basin as an Example. Mar. Pet. Geology. 85, 177-193. doi:10.1016/j.marpetgeo.2017.05.012 
Zhang, K., Jiang, Z., Xie, X., Gao, Z., Liu, T., Yin, L., et al. (2018). Lateral Percolation and its Effect on Shale Gas Accumulation on the Basis of Complex Tectonic Background. Geofluids 2018, 5195469. doi:10.1155/2018/5195469

Zhang, K., Zhuo, L., Jiang, S., Jiang, Z., Wen, M., Jia, C., et al. (2018). Comparative Analysis of the Siliceous Source and Organic Matter Enrichment Mechanism of the Upper Ordovician-Lower Silurian Shale in the Upper-Lower Yangtze Area. Minerals 2018 (8), 283. doi:10.3390/min8070283

Zhang, K., Song, Y., Jiang, S., Jiang, Z., Jia, C., Huang, Y., et al. (2019). Accumulation Mechanism of marine Shale Gas Reservoir in Anticlines: a Case Study of the Southern Sichuan Basin and Xiuwu Basin in the Yangtze Region. Geofluids 2019, 5274327. doi:10.1155/2019/5274327

Zhang, K., Song, Y., Jiang, S., Jiang, Z., Jia, C., Huang, Y., et al. (2019). Mechanism Analysis of Organic Matter Enrichment in Different Sedimentary Backgrounds: A Case Study of the Lower Cambrian and the Upper Ordovician-Lower Silurian, in Yangtze Region. Mar. Pet. Geology. 99 (2019), 488-497. doi:10.1016/j.marpetgeo.2018.10.044

Zhang, K., Song, Y., Jiang, S., Jiang, Z., Jia, C., Huang, Y., et al. (2019). Shale Gas Accumulation Mechanism in a Syncline Setting Based on Multiple Geological Factors: An Example of Southern Sichuan and the Xiuwu Basin in the Yangtze Region. Fuel 241 (2019), 468-476. doi:10.1016/j.fuel.2018.12.060

Zhang, K., Song, Y., Jia, C., Jiang, Z., Jiang, S., Huang, Y., et al. (2019). Vertical Sealing Mechanism of Shale and its Roof and Floor and Effect on Shale Gas Accumulation, a Case Study of marine Shale in Sichuan basin, the Upper Yangtze Area. J. Pet. Sci. Eng. 175 (2019), 743-754. doi:10.1016/ j.petrol.2019.01.009

Zhang, K., Peng, J., Liu, W., Li, B., Xia, Q., Cheng, S., et al. (2020). The Role of Deep Geofluids in the Enrichment of Sedimentary Organic Matter: a Case Study of the Late Ordovician-Early Silurian in the Upper Yangtze Region and Early Cambrian in the Lower Yangtze Region, south China. Geofluids 2020, 8868638. doi:10.1155/2020/8868638

Zhang, K., Peng, J., Wang, X., Jiang, Z., Song, Y., Jiang, L., et al. (2020). Effect of Organic Maturity on Shale Gas Genesis and Pores Development: A Case Study on marine Shale in the Upper Yangtze Region, South China. Open Geosciences 12 (2020), 1617-1629. doi:10.1515/geo-2020-0216

Zhang, K., Jia, C., Song, Y., Jiang, S., Jiang, Z., Wen, M., et al. (2020). Analysis of Lower Cambrian Shale Gas Composition, Source and Accumulation Pattern in Different Tectonic Backgrounds: A Case Study of Weiyuan Block in the Upper Yangtze Region and Xiuwu Basin in the Lower Yangtze Region. Fuel 263 (2020), 115978. doi:10.1016/j.fuel.2019.115978

Zou, C., Dong, D., Wang, Y., Li, X., Huang, J., Wang, S., et al. (2015). Shale Gas in China: Characteristics, Challenges and Prospects (I). Pet. Exploration Dev. 42
(6), 689-701. (in Chinese with English abstract). doi:10.1016/s1876-3804(15) 30072-0

Zou, C., Dong, D., Wang, Y., Li, X., Huang, J., Wang, S., et al. (2016). Shale Gas in China: Characteristics, Challenges and Prospects (II). Pet. Exploration Dev. 432, 182-196. doi:10.1016/s1876-3804(16)30022-2

Zou, C., Zhao, Q., Dong, D., Yang, Z., Qiu, Z., Liang, F., et al. (2017). Geological Characteristics, Main Challenges and Future prospect of Shale Gas. J. Nat. Gas Geosci. 2 (5-6), 273-288. doi:10.1016/j.jnggs.2017.11.002

Zou, C., Yang, Z., Zhang, G., Tao, S., Zhu, R., Yuan, X., et al. (2019). Establishment and Practice of Unconventional Oil and Gas Geology. Acta Geologica Sinica 93 (1), 12-23.

Zou, C., Pan, S., Jing, Z., Gao, J., Yang, Z., Wu, S., et al. (2020). Shale Oil and Gas Revolution and its Impact. Acta Petrolei Sinica 41 (1), 1-12.

Zuo, J., Yu, M., Hu, S., Song, H., Wei, W., Shi, Y., et al. (2019). Experimental Investigation on Fracture Mode of Different Thick Rock Strata. J. Mining Strata Control. Eng. 1 (1), 013007.

Conflicts of Interest: Author YL was employed by PetroChina Southwest Oilfield Company. Author ZC was employed by CNPC (China National Petroleum Corporation).

The remaining authors declare that the research was conducted in the absence of any commercial or financial relationships that could be construed as a potential conflict of interest.

The handling editor declared a past co-authorship with one of the authors ZJ and SJ.

Publisher's Note: All claims expressed in this article are solely those of the authors and do not necessarily represent those of their affiliated organizations, or those of the publisher, the editors, and the reviewers. Any product that may be evaluated in this article, or claim that may be made by its manufacturer, is not guaranteed or endorsed by the publisher.

Copyright (c) 2021 Zhang, Zhang, Song, Jiang, Jiang, Wang, Li, Yin, Chen, Li, Yuan, Liu, Han, Tang, Yang and Zeng. This is an open-access article distributed under the terms of the Creative Commons Attribution License (CC BY). The use, distribution or reproduction in other forums is permitted, provided the original author(s) and the copyright owner(s) are credited and that the original publication in this journal is cited, in accordance with accepted academic practice. No use, distribution or reproduction is permitted which does not comply with these terms. 